\title{
Sír
}

our future through science

\section{CSIR Contribution to Defining Adaptive Capacity in the Context of Environmental Change}

\author{
$2^{\text {nd }}$ Interim Report
}

Approved for public release; distribution unlimited
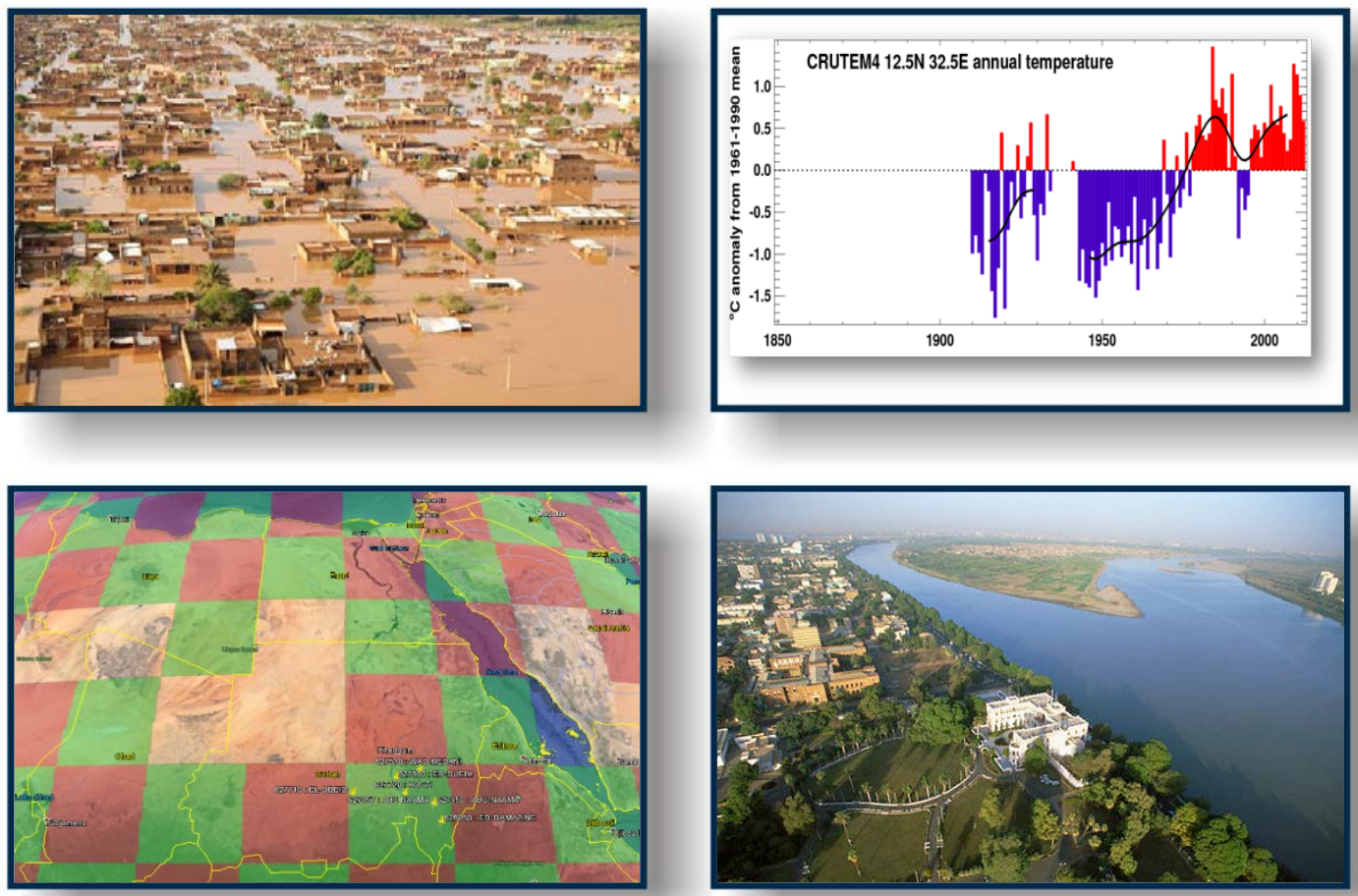


\section{Report Documentation Page}

Form Approved OMB No. 0704-0188

Public reporting burden for the collection of information is estimated to average 1 hour per response, including the time for reviewing instructions, searching existing data sources, gathering and maintaining the data needed, and completing and reviewing the collection of information. Send comments regarding this burden estimate or any other aspect of this collection of information, including suggestions for reducing this burden, to Washington Headquarters Services, Directorate for Information Operations and Reports, 1215 Jefferson Davis Highway, Suite 1204, Arlington VA 22202-4302. Respondents should be aware that notwithstanding any other provision of law, no person shall be subject to a penalty for failing to comply with a collection of information if it does not display a currently valid OMB control number.

\begin{tabular}{|c|c|c|}
\hline $\begin{array}{l}\text { 1. REPORT DATE } \\
\mathbf{3 0} \text { JUN } \mathbf{2 0 1 4}\end{array}$ & 2. REPORT TYPE & $\begin{array}{l}\text { 3. DATES COVERED } \\
\mathbf{0 0 - 0 0 - 2 0 1 4} \text { to 00-00-2014 }\end{array}$ \\
\hline \multirow{3}{*}{\multicolumn{2}{|c|}{$\begin{array}{l}\text { CSIR Contribution to Defining Adaptive Capacity in the Context of } \\
\text { Environmental Change }\end{array}$}} & $\begin{array}{l}\text { 5a. CONTRACT NUMBER } \\
\text { W911NF-14-1-0113 }\end{array}$ \\
\hline & & 5b. GRANT NUMBER \\
\hline & & 5c. PROGRAM ELEMENT NUMBER \\
\hline \multirow{3}{*}{\multicolumn{2}{|c|}{ 6. AUTHOR(S) }} & 5d. PROJECT NUMBER \\
\hline & & 5e. TASK NUMBER \\
\hline & & 5f. WORK UNIT NUMBER \\
\hline \multicolumn{2}{|c|}{$\begin{array}{l}\text { 7. PERFORMING ORGANIZATION NAME(S) AND ADDRESS(ES) } \\
\text { Council for Scientific and Industrial Research (CSIR),PO Box } \\
\text { 395,Pretoria 0001, South Africa, }\end{array}$} & $\begin{array}{l}\text { 8. PERFORMING ORGANIZATION REPORT } \\
\text { NUMBER } \\
\text {; } \mathbf{1 6 7 5 - E N - 0 1}\end{array}$ \\
\hline \multirow{2}{*}{\multicolumn{2}{|c|}{$\begin{array}{l}\text { 9. SPONSORING/MONITORING AGENCY NAME(S) AND ADDRESS(ES) } \\
\text { Army Engineer Research \& Development Center - International } \\
\text { Research Office, ERDC-IRO, ATT: RICHMOND, Unit 4507, APO, AE, } \\
\text { 09421 }\end{array}$}} & 10. SPONSOR/MONITOR'S ACRONYM(S) \\
\hline & & $\begin{array}{l}\text { 11. SPONSOR/MONITOR'S REPORT } \\
\text { NUMBER(S) } \\
\text { 1675-EN-01 }\end{array}$ \\
\hline
\end{tabular}

12. DISTRIBUTION/AVAILABILITY STATEMENT

Approved for public release; distribution unlimited

13. SUPPLEMENTARY NOTES

14. ABSTRACT

The Defining Adaptive Capacity in the Context of Environmental Change (DACE) project set out to understand the relationship between environmental factors and human security for developing regions. In this reporting period (month 2-3) the team collected and organised data related to the above objective. The project workshop held in Washington DC in February 2014 served to further develop the analytic framework and discuss data overlay as part of the data fusion process. The next steps are to further define and confirm correlative relationships between the datasets.

15. SUBJECT TERMS

16. SECURITY CLASSIFICATION OF:

a. REPORT unclassified b. ABSTRACT unclassified c. THIS PAGE unclassified
17. LIMITATION OF ABSTRACT

Same as Report (SAR)
18. NUMBER 19a. NAME OF OF PAGES RESPONSIBLE PERSON

12 


\title{
GIR
}

our future through science

\section{CSIR Contribution to Defining Adaptive Capacity in the Context of Environmental Change}

\author{
$2^{\text {nd }}$ Interim Report
}

Report prepared for:

ERDC-IRO

ATTN: Julian Richmond

86-88 Blenheim Crescent

West Ruislip

Middlesex, HA4 7HL

United Kingdom
Report prepared by:

Karen Nortje and Marius Claassen

CSIR

PO Box 395

Pretoria

0001, South Africa

Date:

30 June 2014

CC CSIR 2014 


\section{CONTENTS}

1. ABSTRACT 2

2. INTRODUCTION 2

3. PROJECT TASKS AND PROGRESS 3

3.1 Tasks 3

3.2 Progress 4

3.3 Red Flags 8

3.4 What's next? $\quad 9$

4. COST AND PAYMENT SCHEDULE 10

4.1 Cost and Price 10

4.2 Payment schedule 10

$\begin{array}{lll}4.3 & \text { References } & 10\end{array}$ 


\section{ABSTRACT}

The Defining Adaptive Capacity in the Context of Environmental Change (DACE) project set out to understand the relationship between environmental factors and human security for developing regions. In this reporting period (month 2-3) the team collected and organised data related to the above objective. The project workshop held in Washington DC in February 2014 served to further develop the analytic framework and discuss data overlay as part of the data fusion process. The next steps are to further define and confirm correlative relationships between the datasets.

\section{INTRODUCTION}

The CSIR and ERDC are jointly doing research on Defining Adaptive Capacity in the Context of Environmental Change (DACE) under grant W911NF-14-1-0113. The research is based on the premise that human security and environmental security is inextricably linked and that a better understanding the relationship between human and environmental security will assist in reducing vulnerabilities and improving stability. The grant supports CSIR and ERDC research in adaptation to water-related impacts of climate change. The research is based on a comparison of historic human responses to environmental change in the Mississippi River and the Nile River, as measured by human security indicator datasets and environmental variability data. The overall goal is to measure regional adaptive capacity and thus understand how to facilitate regional stability that can withstand threats imposed by environmental impacts (Figure 1). Based on the outcome of this analysis, a set of metrics will be developed that will assist in measuring the adaptive capacity of a region based on past behaviour and capabilities to cope with physical or environmental changes.

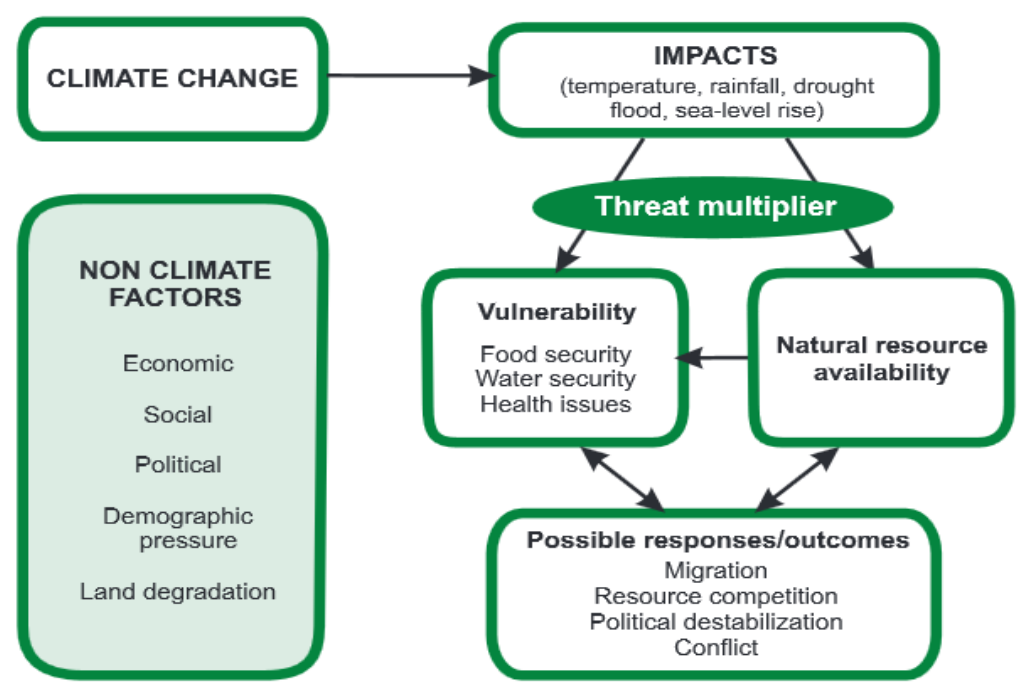

Figure 1. Conceptual Framework (UNEP, 2011) 
This second interim report presents progress on the data overlay component of the data fusion phase. The data overlay phase supports the understanding and identification of vulnerabilities in developing regions that inherently have fewer institutional capabilities to handle large-scale changes. The data overlay supports the qualitative and quantitative analysis of adaptive capacity compares areas in the Mississippi and Nile Basin, with the Mississippi case area serving as a more controlled case study with the Nile Basin representing a context with more limited historical data. Environmental change and human behaviour over the hundred year time scale (1910-2010) are being used for the analysis. The comparison of environmental change (eg. precipitation and temperature trends) and the corresponding human behavioural responses (eg food access and migration patterns) will provide an input to metric creation, contingent on evidence that changes in local stability are related to environmental change. These metrics will be used to measure areas of vulnerability within both study regions.

\section{PROJECT TASKS AND PROGRESS}

\subsection{Tasks}

\begin{tabular}{|l|l|l|l|}
\hline No. & Task & Description & Target date \\
\hline 1 & Datasets & $\begin{array}{l}\text { 1.1 Inputs to environmental and human } \\
\text { security datasets }\end{array}$ & 31 Jan 2014 \\
\hline 2 & Data fusion & 2.1 Data overlay & 31 March 2014 \\
\hline 2 & Data fusion & $\begin{array}{l}\text { 2.2 Data analysis } \\
\text { 2.3 Additional data collection }\end{array}$ & 30 Sept 2014 \\
\hline 3 & Correlation & 3.1 Compare results & 30 Sept 2014 \\
\hline 4 & Metrics & 4.1 Develop adaptive capacity metrics & 31 March 2015 \\
\hline 4 & Metrics & 4.2 Identify areas of vulnerability & 30 June 2015 \\
\hline
\end{tabular}

This report pertains to Task 2.1: Data overlay. The Task has been described as follows in the Project Plan:

\section{Task 2: Data Fusion:}

Task 2.1: Overlay the environmental dataset produced from the reanalysis with the historic human indicator data. This task will be done for both the Mississippi River and the Nile River. The CSIR will provide technical assistance with this task, which will be achieved through a joint workshop at ERDC. 


\subsection{Progress}

CSIR project members, Marius Claassen and Karen Nortje journeyed to Washington DC in February 2014 during the week of the $17^{\text {th }}$ to the $21^{\text {st }}$ (Figure 1). During this week the CSIR collaborated in a joint workshop with ERDC team members, Swathi Veeravalli (project leader), Laura Harding and Nicole Wayant. The agenda (Figure 3) included an overview of the objectives and discussions on the data to consider the relationships and linkages over time and space for the two project case areas. Significant time was spent to refine the methodology whereas the team also discussed joint participation in related activities.

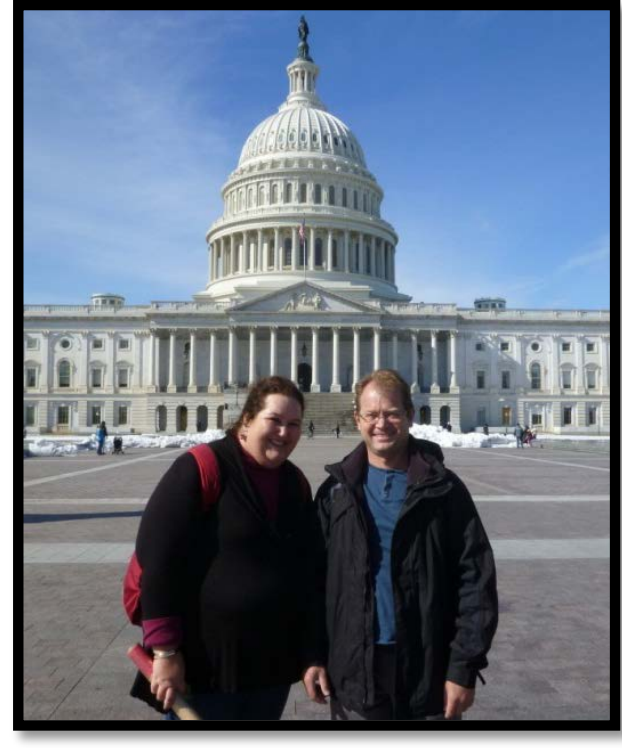

Figure 2. South African team members, Karen Nortje and Marius Claassen in Washington DC with the Capitol in the background

TEC-CSIR 6.1 Planning Meeting

Defining Adaptive Capacity in the Context of Environmental Change Topographic Engineering Center

7701 Telegraph Road, Alexandria VA 22315 February 17 - February 21,2014

\begin{tabular}{|c|c|c|c|}
\hline \multirow{6}{*}{$\begin{array}{c}\text { Tuesday, February } 18, \\
2014\end{array}$} & $0930-1030$ & $\begin{array}{l}\text { Arrive at } \mathrm{TEC} / \text { Security } \\
\text { in processing }\end{array}$ & Marius/Karen \\
\hline & $1030-1130$ & Administration & Marius/Karen \\
\hline & $1230-1330$ & PMP review & All \\
\hline & $1330-1430$ & Lunch & All \\
\hline & $1430-1530$ & $\begin{array}{c}\text { Environmental Data } \\
\text { Review }\end{array}$ & Nikki Lead \\
\hline & $1530-1630$ & Task Identification & All \\
\hline \multirow{6}{*}{$\begin{array}{l}\text { Wednesday, February } 19 \text {, } \\
2014\end{array}$} & $0930-1030$ & Methodology & All \\
\hline & $1030-1130$ & Correlation Analysis & All \\
\hline & $1230-1330$ & $\begin{array}{l}\text { What do we mean by } \\
\text { Metrics? }\end{array}$ & $\begin{array}{c}\text { CR-4 } \\
\text { All }\end{array}$ \\
\hline & $1330-1430$ & Lunch & \\
\hline & $1430-1530$ & $\begin{array}{l}\text { Climate/Weather/Human } \\
\text { Security Briefing }\end{array}$ & $\begin{array}{c}\text { CR-4 } \\
\text { (Swathi/Laura } \\
\text { lead)All } \\
\end{array}$ \\
\hline & $1530-1630$ & Review & \\
\hline \multirow{6}{*}{$\begin{array}{c}\text { Thursday, February } 20, \\
2014\end{array}$} & $0930-1030$ & \multirow{2}{*}{ Conceptual Framework } & CR-2 \\
\hline & $1030-1130$ & & All \\
\hline & $1230-1330$ & Lunch & \\
\hline & $1330-1430$ & Next Steps & \\
\hline & $1430-1530$ & & \\
\hline & $1530-1630$ & & \\
\hline \multirow{3}{*}{ Friday, February 21, 2014} & $0930-1030$ & \multirow{2}{*}{ SA workshop planning } & \multirow{2}{*}{ Swathi/Marius/Karen } \\
\hline & $1030-1130$ & & \\
\hline & $\frac{1230-1330}{1330-1630}$ & Lunch & \\
\hline
\end{tabular}

Figure 3. Agenda for the joint CSIR and ERDC workshop in Washington DC. 
Further progress was made with regards access to the following datasets for both qualitative and quantitative, and environmental and human security factors:

\begin{tabular}{|l|l|}
\hline 1910-2010 Quantitative & $\begin{array}{l}\text { Hyde; GIMMS; MODIS/NDVI; HURDAT; Radiosonde; NCAR, } \\
\text { Flow, ENSO }\end{array}$ \\
\hline 1910-2010 Qualitative & $\begin{array}{l}\text { Human dynamics in the MS (Primary and secondary) } \\
\text { Human dynamics in the Sudan (Secondary) }\end{array}$ \\
\hline
\end{tabular}

An example of climate data presentation in presented in Figure 4. The map shows the climate variation for the 100-year study period, whereas the graph shows the annual deviation from the long term mean. Figure 5 shows a representation of river runoff time series data, with the different gauging stations being shown on the map and the time series data for the Malakal gauging station (GRDC-no.: 1673600) on the White Nile being shown in the graph.

\section{Climate}

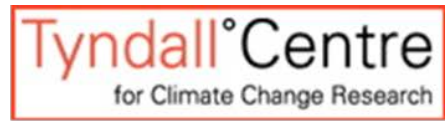

Year-by-year variations over the 20th century (1901-2000)

- cloud cover

- diurnal temperature range

- frost day frequency

- daily minimum temperature

- daily mean temperature

- daily maximum temperature

- precipitation total

- vapour pressure

- wet day frequency

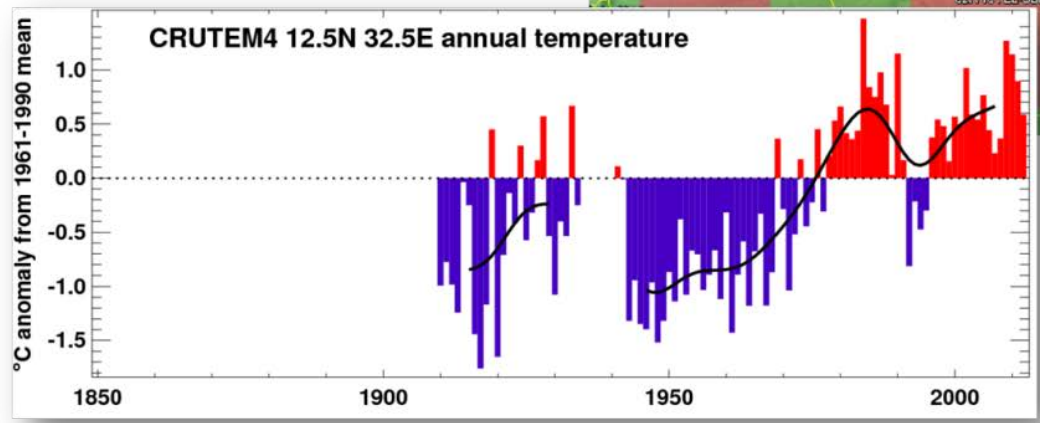

Figure 4. Climate data presentation (Tyndall Centre, 2014) 


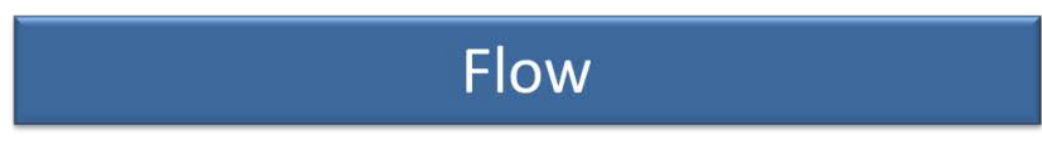

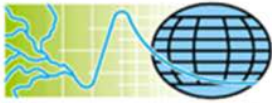

(2) GRDC
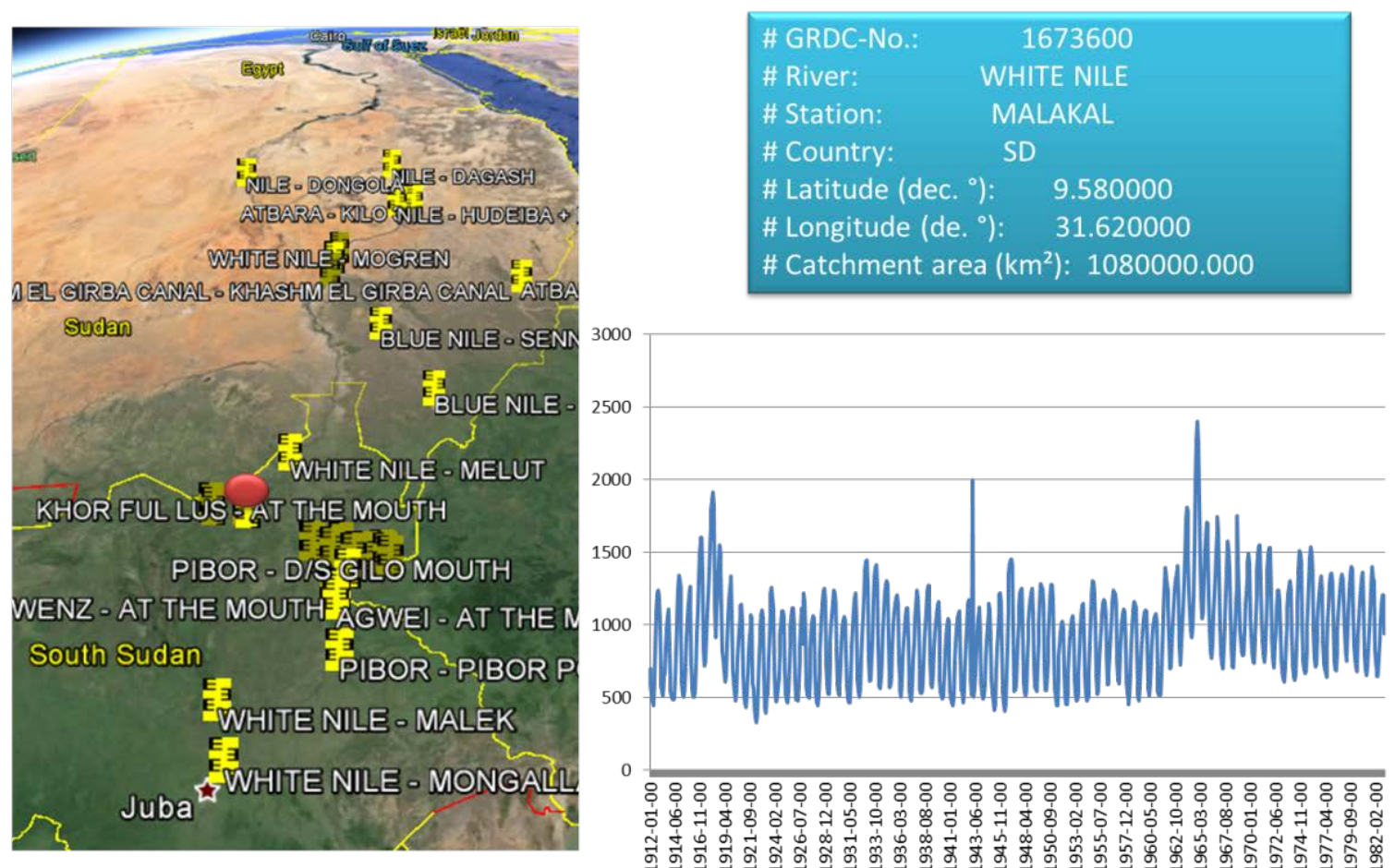

Figure 5. Hydrology data presentation (Global Runoff Data Centre, 2014)

During this joint workshop the team tested the composite human security indicator dataset developed during Task 1 . This dataset took into consideration the contextual nuances of the two case study areas, the Mississippi River and the Nile River. This new dataset comprised of a number of main categories, namely: economic, health, personal, community, political, food, environmental, cultural/spiritual, physical infrastructure and livelihoods. Each of these categories also had sub-categories which were specifically linked to human adaptive capacity within the context of environmental change.

In order to test the new dataset, an excel spreadsheet was created where the team then input data both spatially namely, national, regional and local, and temporally according to decade. For example: 


\begin{tabular}{|c|c|c|c|}
\hline \multirow{10}{*}{ year } & \multirow{10}{*}{ spa } & economic & health \\
\hline & & stsus affinsmeis/system & Howkt trends \\
\hline & & Leweldincame & .4 ceess tos sto $11 \mathrm{WN}$ \\
\hline & & Stricioney a incomes & 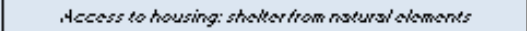 \\
\hline & & tyoses d employment & 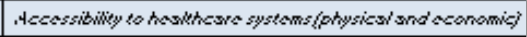 \\
\hline & & smploymentises & 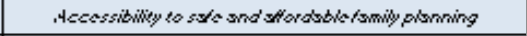 \\
\hline & & And temere system & modicalese \\
\hline & & divsion disbour & Typochawher system \\
\hline & & & indsrem mortsiky \\
\hline & & & fertikyoses \\
\hline \multirow{5}{*}{1991} & National & \multirow{5}{*}{$\begin{array}{l}\text { GNll: } 440 \\
\text { GDP: } 11.379 .222 .223 \\
\text { Unemploument } 1 \% \text { of total } \\
\text { labour forcel: } 15.4\end{array}$} & Infant mortalitu rate per 1000 live births: 80 \\
\hline & & & Eertilitu rate (total children per womand: 6.1 \\
\hline & & & \\
\hline & Regional & & \\
\hline & Local & & \\
\hline \multirow{5}{*}{1992} & National & \multirow{5}{*}{$\begin{array}{l}\text { GNll: } 340 \\
\text { GDP: } 7.031933 .410 \\
\text { Inemploument } 1 \% \text { of total } \\
\text { labour forcel: } 15.2\end{array}$} & Infant mortalitu rate per 1000 live births: 79 \\
\hline & & & Eertilitu rate (total children per womanl: 6 \\
\hline & & & \\
\hline & Regional & & \\
\hline & Local & & \\
\hline \multirow{5}{*}{1993} & National & \multirow{5}{*}{$\begin{array}{l}\text { GNl: } 300 \\
\text { GDP: } 8.881 .009 .956 \\
\text { Unemployment } 1 \% \text { of total } \\
\text { labour forcel: } 15.3\end{array}$} & Infant mortalitu rate per 1000 live births: 78 \\
\hline & & & Eertilitu rate (total children per womand: 6 \\
\hline & & & \\
\hline & Regional & & \\
\hline & Local & & \\
\hline \multirow{5}{*}{1994} & National & \multirow{5}{*}{$\begin{array}{l}\text { GNll: } 310 \\
\text { GDP: } 12.793 .798 .349 \\
\text { Wnemploument } 1 \% \text { of total } \\
\text { labour forcel: } 15.1\end{array}$} & Infant mortalitu rate per 1000 live births: 77 \\
\hline & & & Eertilitu rate (total children per womand: 59 \\
\hline & & & \\
\hline & Regional & & \\
\hline & Local & & \\
\hline \multirow{5}{*}{1995} & National & \multirow{5}{*}{$\begin{array}{l}\text { GNV: } 390 \\
\text { GDP: } 13.830 .369 .880 \\
\text { Unemploument } 1 \% \text { of total } \\
\text { labour forcel: } 15.1\end{array}$} & Infant mortalitu rate per 1000 live births: 75 \\
\hline & & & Eertilitu rate (total children per womanl: 5.8 \\
\hline & & & \\
\hline & Regional & & \\
\hline & Local & & \\
\hline
\end{tabular}

Figure 6. An example of the excel spreadsheet created for the Sudan. This snapshot is of the categories 'economic' and 'health' during the years 1991-1995.

The teams are currently in the process of populating the spreadsheet to see whether or not this type of data capturing is appropriate for the purposes of this project.

Lastly, the team have started looking at possible ways of conceptualising the data that is being generated. The following diagram is a draft conceptual model developed in the workshop as a starting point for the analysis that is to follow further along in the project. 


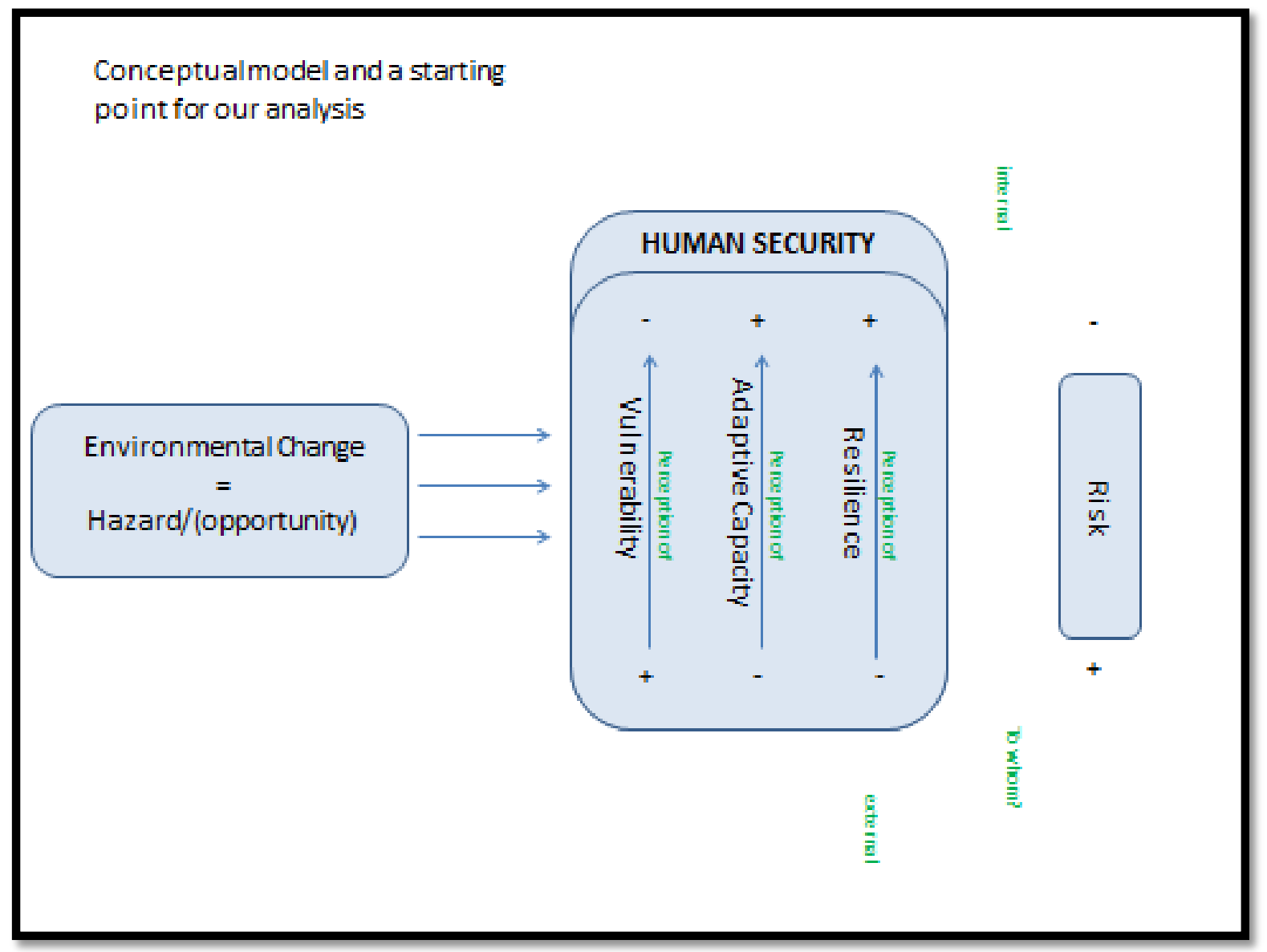

Figure 7. Draft conceptual model developed during the joint workshop in Washington DC in February. It will be used as a starting point for further data analysis.

\subsection{Red Flags}

There are a small number of important issues that needs to be flagged. These are however not show-stoppers and the fact that they have occurred will also be an input into the methodological reflection captured for the project and the overall process.

1) Flow data for the Nile: Quantitative flow data for the Nile is readily available up to 1982. From here on data is difficult to come by. Negotiations on the Cooperative Framework Agreement (CFA) for the use, development, protection, conservation and management of the Nile River Basin and its resources has been ongoing for the past two decades, Both Sudan and Egypt are opposed to the agreement, whereas seven of the upstream countries have already signed it.

2) Qualitative data for the Nile, specifically for the themes the project is looking at is difficult to find, not all encompassing, and not housed in one place. As a result the team has to delve through both academic and grey literature to find the information needed, also data is not complete and may leave gaps in the narrative. 


\subsection{What's next?}

Following on from Task 2.1, the team will now take the data fusion tasks further by focussing on the data fusion processes of data collection and analysis.

Task 2: Data fusion

Task 2.2: Determine if significant changes in environmental variability data correspond to changes in human behavior using both visual (GIS) and statistical methods for each river. Use both the human security indicators and relevant historical case studies to find and affirm a correlation to tangible changes in environmental data. Due to the future transition of this research, past military involvement with populations residing within the watershed will also be researched and the impact will be considered. This task will be facilitated through the joint workshop in which the CSIR will participate.

Task 2.3: To further define and confirm correlative relationships between the two datasets, additional background research will be conducted to consider the following potential historical factors: man-made infrastructure alterations to each river, topographic modifications within each watershed due to urbanization, industrialization, and technological advancements, and changes in environmental policy relating to use of and disposal in the rivers. The CSIR will assist with this research particularly regarding the Nile Basin and selected study area. 


\section{COST AND PAYMENT SCHEDULE}

\subsection{Cost and Price}

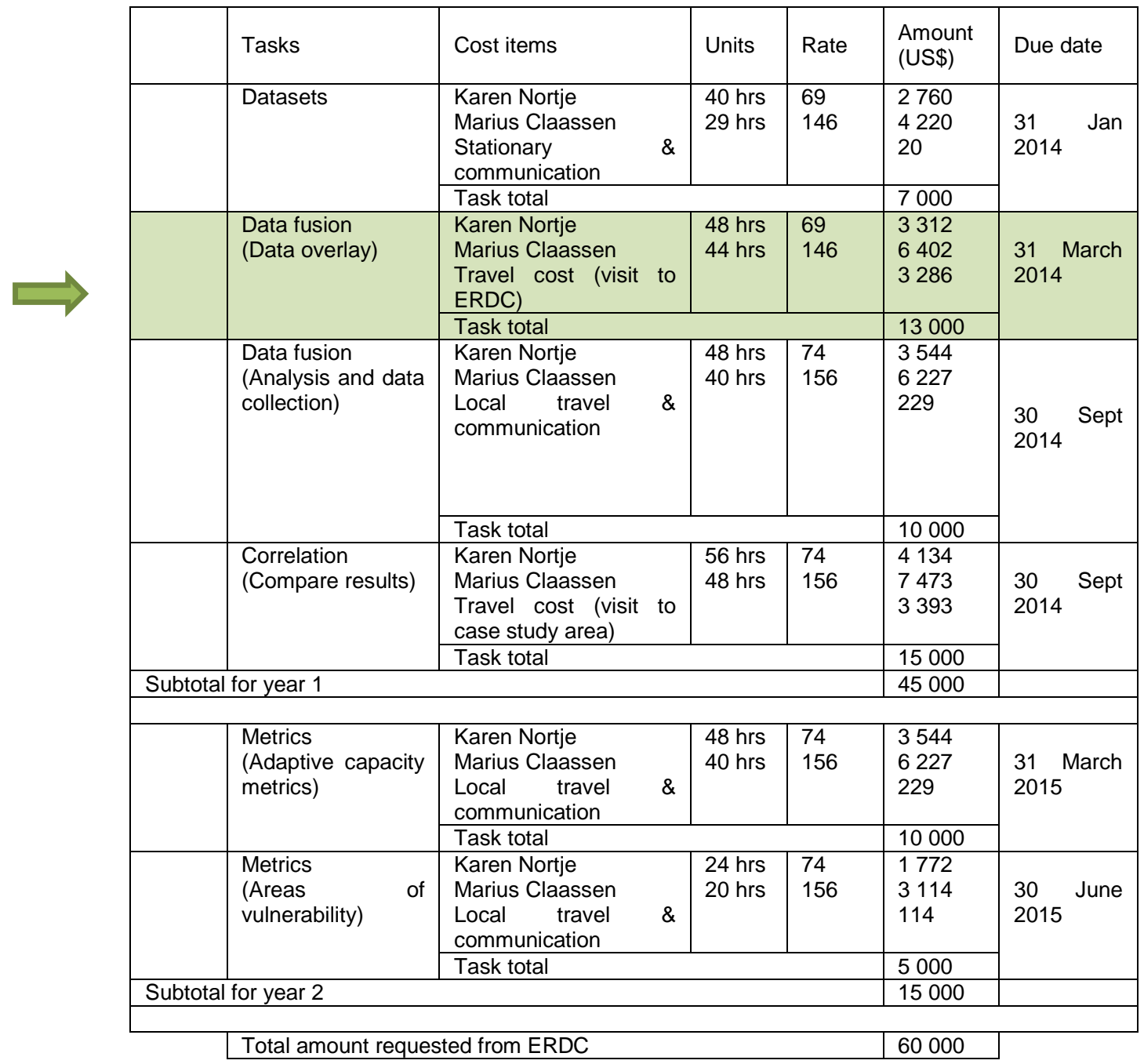

\subsection{Payment schedule}

Invoices will be generated as per the deliverable dates based on approval of deliverables and transfers should be within 30 days of invoice receipt

\subsection{References}

UNEP (2011) Livelihood Security: Climate Change, Migration and Conflict in the Sahel. United Nations Environment Programme. ISBN: 978-92-807-3198-9

Tyndall Centre (2013) Climate grids and derived data-sets.

http://www.cru.uea.ac.uk/ timm/data/index-table.html

Global Runoff Data Centre (2014) River Discharge Time Series.

http://www.bafg.de/GRDC/EN/Home/homepage_node.html 